\title{
A Study of Indoor Environment of Large Glazed Office Building in Semi Arid Climate
}

\section{Mounira Badeche*}

Department of architecture, Faculty of Earth Sciences and Architecture, Larbi Ben Mhidi University, Oum El Bouaghi 04000, Algeria

Department of Architecture and Urban Planning, University 3, Constantine 25000, Algeria

\section{Yasmina Bouchahm}

Department of Architecture and Urban Planning, University 3, Constantine 25000, Algeria

*Corresponding author: badeche_mn@yahoo.fr

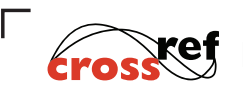

http://dx.doi.org/10.5755/j01.sace.29.2.28008

In recent years the rate of buildings with large glazed facades is rapidly increasing, particularly in office buildings. Where, the creation of a suitable thermal and visual comfort is a significant factor affecting productivity. The use of large glazed facades without adapted shading measure generates thermal and visual discomfort, wich ranges from uncomfortable environment conditions to serious health effects. Specialized work and literature about performance evaluation of large glazed office buildings in relation to their environment are lacking in semi arid climates, characterized by significant intensity of solar radiations in the summer period of the year. This study investigates the impact of large glazing areas on thermal and visual comfort in a sample of naturally ventilated office building located in the semi arid climate of Algeria $\left(36^{\circ}, 17 \mathrm{~N}\right.$ and $\left.7^{\circ}, 23^{\prime} \mathrm{E}\right)$. A Post Occupancy Evaluation technique (POE), being a mainstream activity in the process of building operation phase is used for this purpose. The main objective is to stress practitioners, specifically architects, to take conscious decisions in an early phase of design process. The study clearly highlighted discomfort in the studied office building. It included unacceptable temperature arising from glazed facade; overheating due to excessive solar gains; insufficient ventilation and poor daylighting. The results indicate that such large fenestration system is not recommended in summer time. However, a judicious choice of the glazing size and type by simulation tools must balance lighting and thermal needs.

Keywords: fenestration, indoor environment, post occupancy evaluation, thermal comfort, visual comfort.

Human comfort and well-being are important in workplace. Many researchers have extensively investigated the relationship between the physical environment and other work variables, such as job satisfaction and performance. However, the creation of suitable microclimate in workplace largely depends on the process of building design, during which early-stage critical decisions are made (Tzempelikos and Athienitis Andreas 2007). For instance, architects are responsible for the creation of high-quality indoor environments to provide thermal and visual comfort to increase office workers productivity (Menzies and Wherrett 2005).

In recent years, research has identified the benefits of daylight and sunlight in buildings for occupants' well-being and health, including necessity for the regulation of circadian rhythms (Stone 1999). In the workplace, windows are strongly required for outside view and daylight access (Jam-

\section{Introduction}

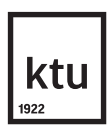

Journal of Sustainable Architecture and Civil Engineering Vol. 2 / No. 29 / 2021 pp. $175-188$ DOI 10.5755/j01.sace.29.2.28008

Received $2020 / 11 / 30$ Accepted after revision 2021/05/31 
rozik et al 2019), which is essential for health and productivity (Chi et al 2011). The design and selection of fenestration systems play a key role in achieving a suitable comfort level.

Therefore, when designing a fenestration system, numerous physical aspects need to be considered, such as visual contact between interior and exterior, daylight use, solar energy gain, glare reduction, thermal loss and thermal comfort. According to (Manz and Urs-Peter 2012), highly glazed spaces can cause significant thermal energy gains or losses in buildings, which affect thermal comfort. In addition, occupants can be adversely affected by the presence of large hot or cold surfaces (Ochoa et al 2012). In which, the thermal characteristics constitute the main technical and constructional criteria influencing a building's microclimate (Isaksson and Karlsson 2006).

From the post-occupancy survey in four buildings, Menzies and Wherrett (2005) showed that a building with energy efficient windows could have high levels of comfort, when the building and the window design work together. Several studies on window energy performance and fenestration design have indicated that the window transparency is a mediator between thermal and visual performance (Laforgue et al 1997). Conversely, optimizing window size for one purpose can hinder reaching another (Ochoa et al 2012, Li 2008). An integrated thermal and natural light examination is therefore required, since these two parameters are interdependent (Tzempelikos and Athienitis Andreas 2007). Laforgue et al. (1997) evaluated the relationship between size, orientation and glazing properties of windows with space heating demand, daylighting and thermal environment. The authors established charts illustrating how combinations of design parameters with minimum space heating demand can be selected.

From the literature survey, it stood out that researchers mainly focused on one topic only; thermal or visual effect of window. However, the present study differs by analyzing the two aspects together, Taking into consideration a geographical location insufficiently investigated. This study aims to analyze indoor environment problems arising in recently glazed-buildings, to inspire practitioners, especially architects, to take purposeful decisions in the earliest stage of architectural design of future buildings.

Materials and Methods
In all climate zones of Algeria, recently realized office buildings are largely glazed. The request of transparency for promoting aesthetics and visual comfort in office buildings may hide achieving suitable indoor conditions concern. Consequently, the use of large part of glass in the building envelope generates considerable problems, overheating, glare and energy loads.

A Post Occupancy Evaluation (POE) technique is used here. It is an inevitable step toward sustainability (Meir et al 2009, Göçer et al 2015). It is a general approach aimed at obtaining feedback about a building's performance in use. POE methods employ a range of techniques which include, IEQ physical measurements, focus group meetings, structured interviews, visual records, occupant survey questionnaires, walkthroughs, and technical measurement of building structure, services and systems (Sanni-Anibire et al 2016, Leaman et al 2010).Based on a quantitative and qualitative analysis of 146 POE projects, Pexin et al found that POE of office buildings are typically focused on occupants' comfort and productivity. The more sophisticated of these utilize both a survey and physical measurements of indoor environment quality (IEQ) (Li et al 2018). In this study the thermal and the visual comfort, which are the most important parameters of indoor environmental quality (IEQ) (Al horr 2016) are considered. Physical data is used here to compare a building's IEQ performance against the norms.

The thermal comfort conditions analysis is based on thermal comfort requirements, to find out the design consequences of large glazing area on thermal conditions in such climate. Regarding daylighting conditions and visual comfort, the measurement of illuminance levels and spatial uniformity were used.

In situ measurements were conducted in the most recurrent and representative typology of office building facades in Algeria. A five story office building naturally ventilated is selected for a post-occupancy evaluation (Fig. 1). It is located in an urban site in Constantine city $\left(36^{\circ}, 17 \mathrm{~N}\right.$ and $\left.7^{\circ}, 23^{\prime} \mathrm{E}\right)$. 


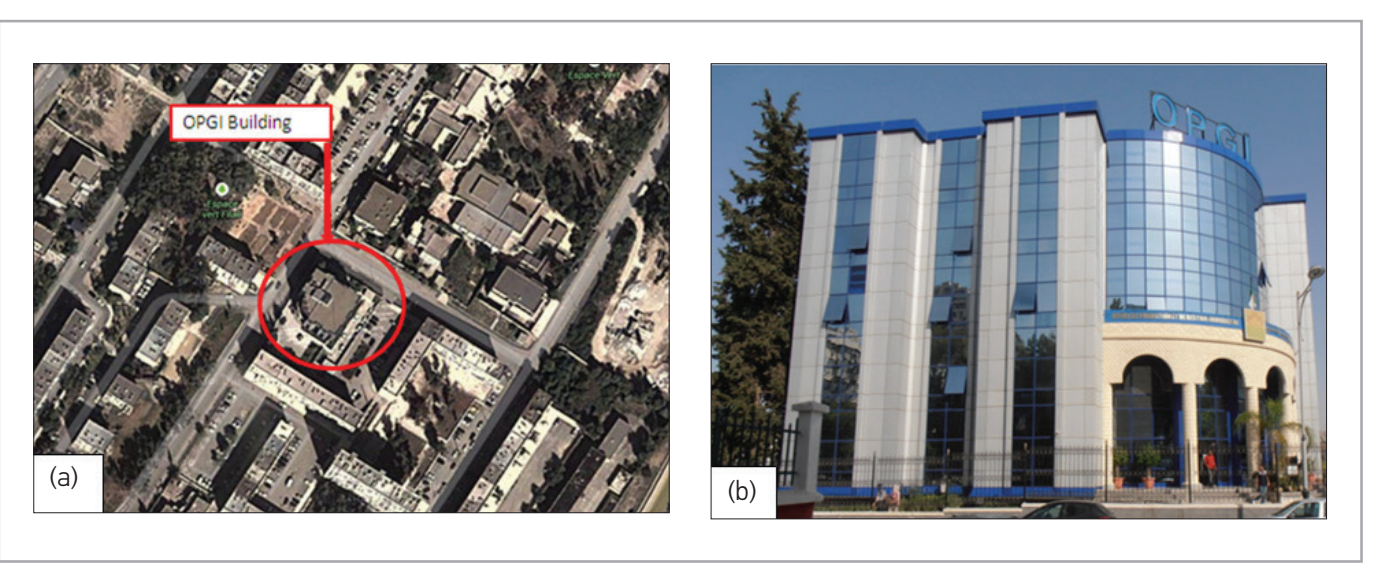

Four office rooms located in diverse orientations in the second floor of the building are selected for in situ measurements evaluation, in the hot period of the year. The situation of selected offices in an intermediate floor allows them a protection of distant or environmental masks. Examined orientations were Northeast (NE), Southeast (SE), southwest (SW) and Northeast and Southeast (the office room has 2 external walls). The Southeastern office room (SE) was the most furnished by thermal and lighting equipment, the reason for which it was the largely analyzed one, in this paper (Fig. 2 and 3).
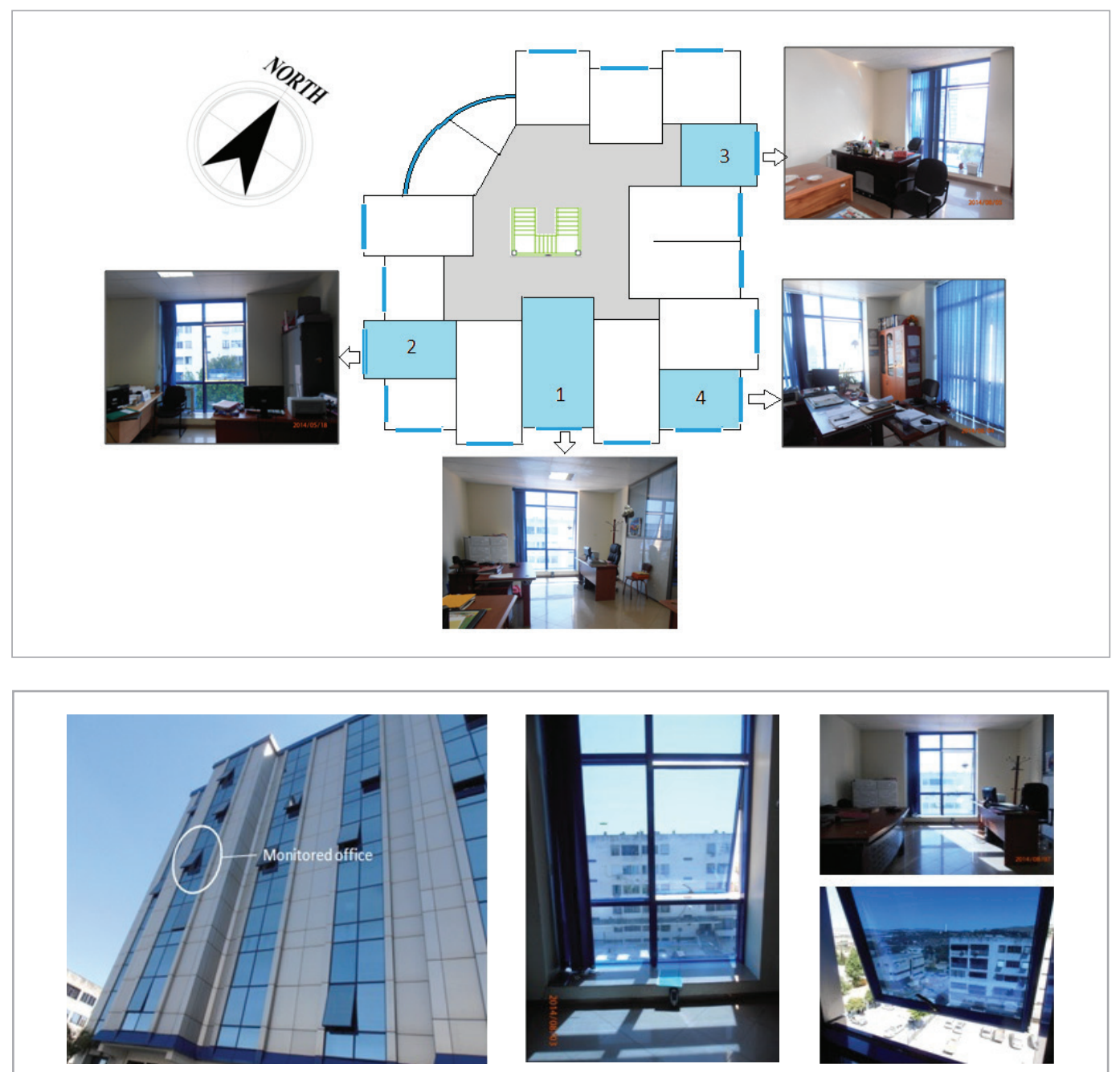

Fig. 1

(a) Location of the OPGI building, (b) View of the building from the main street

Fig. 2

Plan and views of the four monitored spaces

Fig. 3

Detailed views of the glazed area of the building envelope 


\section{Description of the Monitored Building}

The opaque part of the office building envelope is a double hollow brick cavity, while the fenestration system is a double pane glazing windows $5 / 12 / 5$, with a window to wall ratio of $40 \%$.

\section{Table 1}

Main thermal properties of the opaque part of the building envelope

\section{Table 2}

The Main optical and thermal properties, of the glazing used in the monitored building

\begin{tabular}{l|c|c|c|c}
\hline \multicolumn{1}{|c|}{ Materials } & $\begin{array}{c}\text { Conductivity } \\
\lambda(\mathrm{W} / \mathrm{m} . \mathrm{K})\end{array}$ & $\begin{array}{c}\text { Specific } \\
\text { heatcapacity } \\
\mathrm{C}(\mathrm{J} / \mathrm{kg} . \mathrm{K})\end{array}$ & $\begin{array}{c}\text { Density } \\
\rho\left(\mathrm{kg} / \mathrm{m}^{3}\right)\end{array}$ & $\begin{array}{c}\text { Thickness } \\
(\mathrm{cm})\end{array}$ \\
\hline Metal cladding & 210 & 880 & 2700 & 0.3 \\
\hline Cement-mortar & 1.4 & 1080 & 2200 & 2 \\
\hline Hollow-Brick & 0.70 & 936 & 960 & 15 \\
\hline Air & 0.06 & 1274 & 1 & 5 \\
\hline Hollow-Brick & 0.70 & 936 & 960 & 10 \\
\hline Plaster-Mortar & 0.35 & 1010 & 1800 & 2 \\
\hline
\end{tabular}

\begin{tabular}{l|c|c}
\hline \multirow{2}{*}{\begin{tabular}{l|c} 
Luminous \\
Properties
\end{tabular}} & Energetic and Luminous Properties \\
\hline & Visible transmittance \\
VT (\%) & 0.37 \\
\hline \multirow{3}{*}{$\begin{array}{l}\text { Energy } \\
\text { Properties }\end{array}$} & Solar heat gain coefficient (SHGC) & 0.33 \\
\cline { 2 - 3 } & Energy reflectance ER & 0.32 \\
\hline & UV Transmission & 0.13 \\
\hline
\end{tabular}

_ Interior glazing: Clear $5 \mathrm{~mm}$ thickness.

External glazing: Blue glazing, $5 \mathrm{~mm}$ thickness with a blue film of chromium on its exterior face.

The air gap is of $12 \mathrm{~mm}$. Aluminum frame.

Blue curtains made of vertical bands are the unique shading device used to protect the monitored office spaces from solar radiation. The composition of the opaque and the transparent parts of the facade from the outside to the inside is shown in Table 1 and 2 respectively.

\section{Climatic Conditions in Constantine}

Constantine is an inland city of Algeria, located in $36^{\circ}, 17$ North latitude and $7^{\circ}, 23^{\prime}$ East longitude. This location characterized by semi arid climate is classified as Csa by Köppen (2019). Its main feature is the considerable temperature variations, hot summer and very cold and wet winter (Fig. 4). The mean intensity of solar radiation is considerable, as it is about $4230 \mathrm{Wh} / \mathrm{m}^{2} /$ day on a horizontal surface. While, the mean horizontal solar radiation value is $5.037 \mathrm{kWh} / \mathrm{m}^{2} /$ day (N.O.M 2016).

Fig. 4.

The monthly temperatures, in Constantine (N.O.M, 2016)

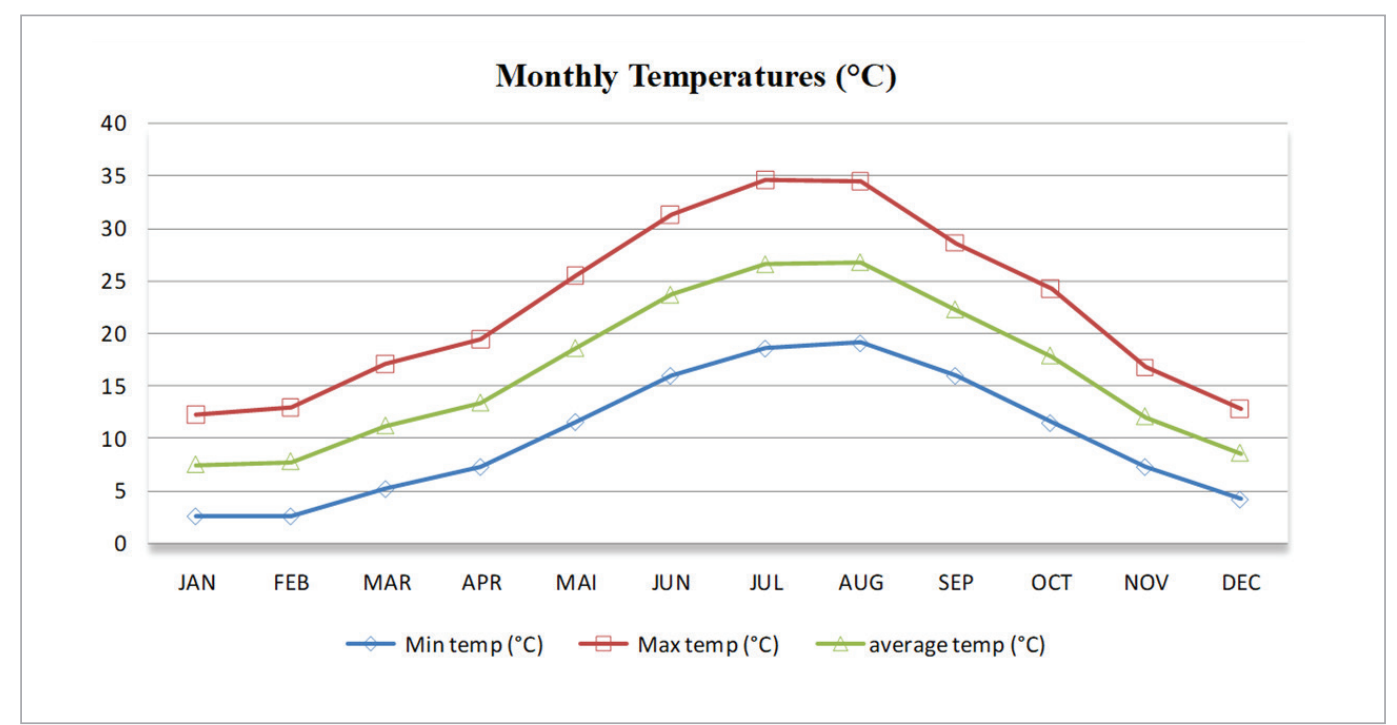




\section{Thermal Comfort Measurement}

Thermal comfort is defined by internationally standards as "a condition of mind which expresses satisfaction with the thermal environment." There are several indices to assess the thermal comfort today. The most widely used is obtained by the PMV equation (Predicted Mean Vote) proposed by Fanger (1970).

The ASHRAE RP-884 standard of measurement procedures applied for indoor thermal comfort (Chyee Toe and kutoba2013) classifies the field data into three classes of expectation. In this study the measurements are linked to class II and class III. The Class II is applied for South Eastern (SE) office room measurements, according to EN 16798-2, 2014 (2014) guidelines. And the Class III protocol is applied in the other office rooms (Table 3). Human metabolic rates and insulation through clothing are classified as subjective factors. These two parameters are estimated in this study. A typical application of the measuring and analysis

\begin{tabular}{|c|c|c|}
\hline $\begin{array}{c}\text { Measured parameters } \\
\text { Class II }\end{array}$ & $\begin{array}{c}\text { Measured parameters } \\
\text { Class III }\end{array}$ & Calculated indices \\
\hline Air temperature & Air temperature & $\begin{array}{l}\text { Predicted Mean } \\
\text { Vote (PMV) }\end{array}$ \\
\hline Air relative humidity & Air relative humidity & \multirow{4}{*}{$\begin{array}{l}\text { Predicted } \\
\text { Percentage of } \\
\text { Dissatisfied } \\
\text { (PPD) }\end{array}$} \\
\hline Air velocity & $x$ & \\
\hline $\begin{array}{l}\text { Internal surface } \\
\text { temperatures }\end{array}$ & $x$ & \\
\hline $\begin{array}{l}\text { Mean radiant } \\
\text { temperature }\end{array}$ & $x$ & \\
\hline
\end{tabular}

Table 3

Measured thermal comfort parameters instrument, Delta ohm is used to relate the six factors of thermal comfort to a sensation scale which is the PMV index, broadly used for estimation of thermal comfort and applied in several standards, such as ANSI/ASHRAE standard 55, 17 (2017); ISO 7730-2005 (2005) and CIBSE Guide A, 2015 (2015). The Predicted Mean Vote (PMV) is calculated in compliance with the standard ISO 7730-2005. Subsequently, the Predicted Percentage of Dissatisfied (PPD) is obtained from the PMV index.

Continuous internal and external measurements were undertaken under representative weather conditions of the warm season, for approximately 5 consecutive days (03to 07 August, 2014); to cover one week of building occupation. Measurements were conducted according to the measurement protocol developed for commercial buildings by the American Society of Heating, refrigeration and air conditioning engineers (ANSI/ASHRAE Standard 55, 17 (2017).

\section{Measuring Equipment and Its Placement}

\section{Class II measuring:}

The monitored Southeastern office room (SE) was instrumented as follows: Three instruments were placed at three positions in the space, to measure the interior ambient temperature and air humidity. The microclimate station Delta Ohm HD32.3 was used to measure several internal parameters: the mean radiant temperature, the relative humidity and the air speed (Table 4).

The objective measurement

\begin{tabular}{|c|c|c|c|}
\hline Instruments & $\begin{array}{l}\text { Measurement } \\
\text { items }\end{array}$ & $\begin{array}{l}\text { Measurement } \\
\text { range }\end{array}$ & Accuracy \\
\hline Orthelec KC6472 & $\begin{array}{c}\text { Temperature } \\
\text { Relative } \\
\text { Humidity }\end{array}$ & $-50^{\circ} \mathrm{C}$ to $+70^{\circ} \mathrm{C}$ & $\pm 3.5 \%$ \\
\hline $\begin{array}{l}\text { Data logger } \\
\text { PCE-HT71 }\end{array}$ & $\begin{array}{c}\text { Temperature } \\
\text { Relative } \\
\text { Humidity }\end{array}$ & $\begin{array}{c}-10 \text { to }+40^{\circ} \mathrm{C} \\
20 \text { to } 80 \%\end{array}$ & $\begin{array}{l} \pm 1^{\circ} \mathrm{C} \\
\pm 3.5 \%\end{array}$ \\
\hline $\begin{array}{l}\text { Weather } \\
\text { Center Oregon } \\
\text { (WMR200) }\end{array}$ & $\begin{array}{l}\text { temperature } \\
\text { humidity } \\
\text { Air speed }\end{array}$ & $\begin{array}{c}-30^{\circ} \mathrm{C} \text { to } 60^{\circ} \mathrm{C} \\
25 \% \text { to } 90 \% \\
2 \sim 56 \mathrm{~m} / \mathrm{s}\end{array}$ & $\begin{array}{c} \pm 1^{\circ} \mathrm{C} \\
\pm 5 \% \\
\pm 3 \mathrm{~m} / \mathrm{s}\end{array}$ \\
\hline $\begin{array}{l}\text { Delta ohm } \\
\text { HD32.3 }\end{array}$ & $\begin{array}{c}\text { Temperature } \\
\text { Humidity } \\
\text { Air speed }\end{array}$ & $\begin{array}{c}-10 \div 80{ }^{\circ} \mathrm{C} \\
5 \% \div 98 \% \\
0 \div 5 \mathrm{~m} / \mathrm{s}\end{array}$ & $\begin{array}{c} \pm 1^{\circ} \mathrm{C} \\
\pm 2.5 \% \\
\pm 0.05 \mathrm{~m} / \mathrm{s}\end{array}$ \\
\hline Extech IR400 & $\begin{array}{c}\text { Surface } \\
\text { temperature }\end{array}$ & -4 to $630^{\circ} \mathrm{F}$ & $\begin{array}{l} \pm 2 \% \text { of } \\
\text { Reading }\end{array}$ \\
\hline $\begin{array}{l}\text { Photo-Radiometer } \\
\text { HD2302 }\end{array}$ & Illuminance & $\begin{array}{c}1.01 \sim 199.99 \times 10^{3} \\
1.02 \mathrm{~lx}\end{array}$ & $<4 \%$ \\
\hline
\end{tabular}

Table 4

Measure instruments installed in the monitored building 
Fig. 5

The spot measurement; air temperature and humidity (0); surface temperature $(\mathbf{+})$.

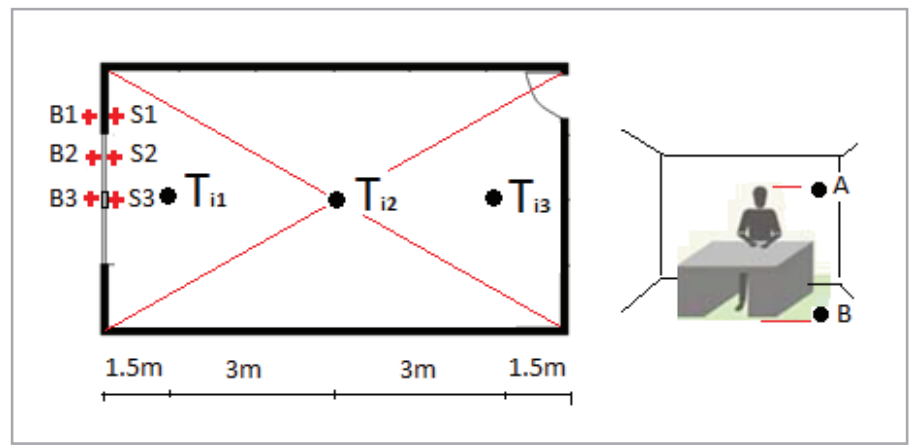

was conducted at around $1.5 \mathrm{~m}$ high from the floor level and $2 \mathrm{~m}, 5 \mathrm{~m}$ and $8 \mathrm{~m}$ inward from the window of the office room. In order to detect the distribution of the air temperature vertically, two measuring points $(A)$ and $(B)$ were selected for measurement, confirming to recommended measurement height for a seated and standing person (ANSI/ASHRAE Standard 55, 17) (2017) (Fig. 5). The surface temperatures were continuously measured between 8:00 and 16:30 daily, by a handheld infrared thermometer with laser pointer (Extech IR400), at some selected points (Fig. 5).

A weather station (Oregon scientific) was mounted in the immediate environment of the tested building to measure the temperature, the relative humidity and the wind speed.

\section{Class III measuring}

The monitoring space was instrumented as follows: measurement of air temperature and relative humidity were undertaken at one measuring point, which is the center of the space. Office rooms considered here are those orientated to (NE), (NE/SE), and (SW).

\section{Visual comfort measurements}

The importance of daylight in buildings is nowadays of particular interest, in terms of visual comfort and well-being. The presence of light in interior spaces increases the human spirit while reduces eye and body fatigue (Nasrollahi and Shokry 2020). Visual comfort is evaluated by illuminance measurement on task areas. The horizontal illuminance at the desk level is used here to evaluate daylighting availability in the space, and the uniformity rate. Daylighting measurements are

\section{Fig. 6}

The grid of illuminance points in the office space

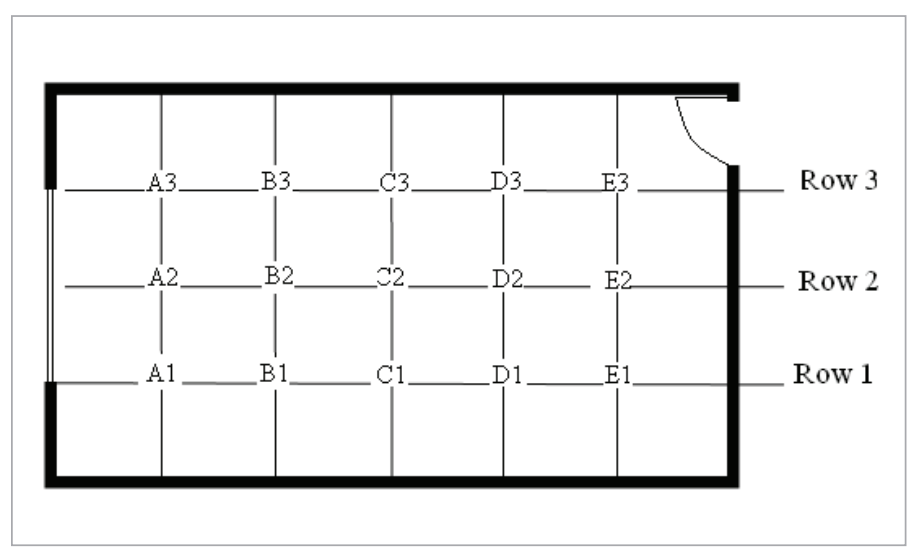

carried out without the presence of lighting, during a partly cloudy day, referring to standard (EN 16798-2 2014), using the Photo-Radiometer HD 2302 and an orthogonal grid of 15 measurement points covering the total office area. The used grid has regular intervals $(1.5 \mathrm{~m})$ at $0.75 \mathrm{~m}$ above the floor level. This value corresponds to the work plane (Fig. 6).

\section{Building schedule}

The building thermal and visual behaviour in real working conditions was analyzed. During the measuring period, employees occupied the office rooms from 8:00 to 16:30. The windows were fully opened to allow air entering during working hours. Blue curtains are used to protect spaces from solar radiation. Occupants kept them closed to protect themselves from UV rays, during all the measuring period, except at illuminance measurement time, whereby we opened them for few minutes and then close them once measurements are taken. 


\section{Air Temperature}

From Fig. 7, we clearly notice that the temperature values (Ti1, Ti2 and Ti3), relating to the three measurement stations placed in the SE office room evolve in the same way and with a slight difference of the order of $0.25^{\circ} \mathrm{C}$, and have very high values, indicating a warm indoor environment. Internal environment was hot, since the mean internal temperature was $29.78^{\circ} \mathrm{C}$. This is attested by thermal behaviour of occupants who open the door to generate air movement to improve their comfort, when these high temperatures occurred during the workday. It is equally observed from the same Figure, that the outdoor temperature for the measured period has a mean diurnal variation of $23.6^{\circ} \mathrm{C}$, while the simultaneous indoor temperature varied with a mean diurnal variation of only about $4.4^{\circ} \mathrm{C}$. This can be explained by the thermal properties of the external wall. As the office space had neither a significant thermal storage nor an air conditioning source, the indoor environmental conditions for the measuring period, followed the outdoor conditions with attenuation of temperature extremes.

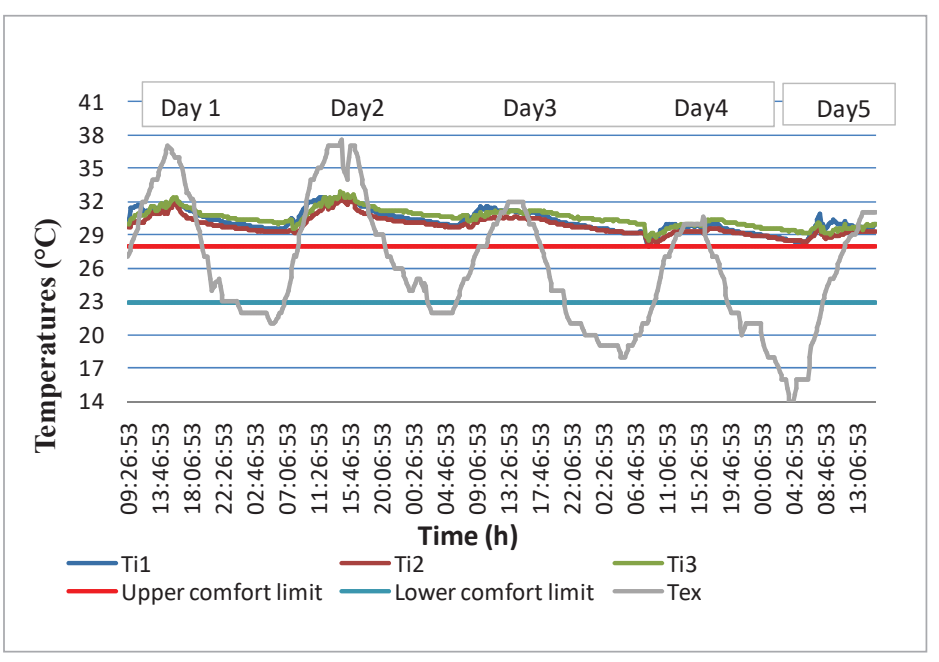
Interior air temperatures curve (Ti2) in Fig. 8 displays information on overheating occurring inside the office space. The air temperatures is gradually rising at daytime from around 9:00 to 15:00, with values between 27.9 and $32.3^{\circ} \mathrm{C}$, well above the upper limit of summer comfort zone of Constantine $\left(27.9^{\circ} \mathrm{C}\right)$. The comfort zone limit was calculated, referring to ANSI/ASHRAE Standard 55, 17 (2017) and

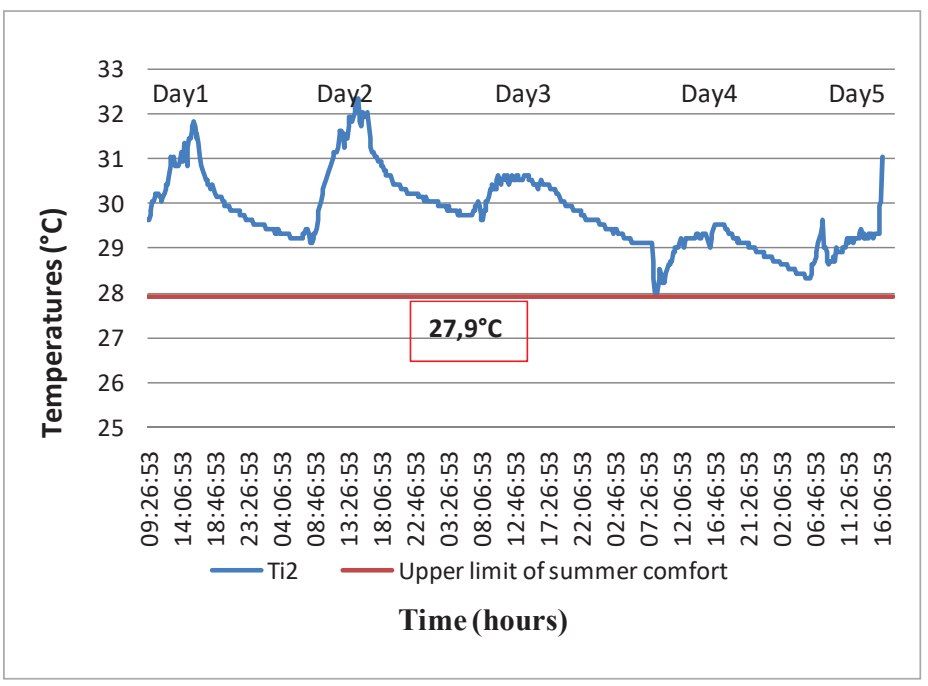
according to (Eq.1).

$$
\text { Top }=17,8+0.31 \times \text { tpma (out) }
$$

where:Top is the indoor operative temperature $\left({ }^{\circ} \mathrm{C}\right.$ ); tpma (out) is the prevailing mean outdoor air temperature.

Office workers perceived discomfort during the entire (100\%) monitored time. The presence of overheating in the office space is the effect of high external air temperatures, solar gains and lack of ventilation. Indeed, the air speed measured during this field study was skewed towards rather low values (in the range of $0-0.22 \mathrm{~m} / \mathrm{s}$ ). The presence of air stagnation in the office space is certainly felt 
by occupants, in fact ASHRAE Standard 55, 17 (2017) indicates that the ideal air speed must range from 0.2 to $1.50 \mathrm{~m} / \mathrm{s}$, in warm climates. In addition, while external air temperature dropped showing a potential for night ventilation technique, the internal temperature never fell below $27.9^{\circ} \mathrm{C}$, for instance in the Day 4, external temperature dropped to $14^{\circ} \mathrm{C}$ at 03:50 (Fig. 8). The ventilation lack is due to occupant's behaviour; which often kept the window closed before leaving the space, to prevent drafts that may disturb papers, and to increase security as well (Badeche 2018). As a result, excess heat is accumulated in the monitored space the following day. The low possibility for air movement between outdoor and indoor deteriorates the situation in the daytime. This is due to the effective opening which represents only about $9.8 \%$ of the entire glazed area in its fully open position (Fig. 3). It is obvious that it affect the potential for convective cooling and occupant's thermal comfort (Wu, 2015).

\section{Air Humidity}

Low levels of relative humidity can cause discomfort through drying of the eyes and mucous membranes and skin. High levels makes the area feel stuffy. Relative humidity measured during this field study varies considerably throughout the day between $34 \%$ and $49.9 \%$. This range is within the standards of the American Society of Heating, Refrigerating, and Air Conditioning Engineers, which recommends a relative humidity $(\mathrm{RH})$ of 30 to $60 \%$ for building occupants, while working at a desk (ASHRAE Standard 55-2010).

\section{Surface Temperatures}

To evaluate envelope thermal behaviour, in situ measurement of Day 1 (03 August 2014) was selected as a typical day. The inside and outside surface temperatures of walls and window were

Fig. 9

Internal surface temperature of external wall for

03/08/2014

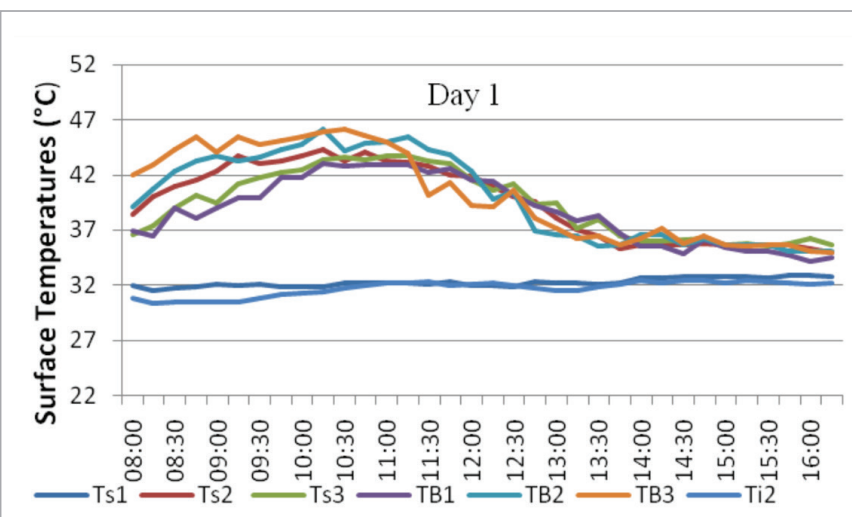

Time (hours)

Fig. 10

Local discomfort caused by radiant asymmetry. $\Delta \mathrm{t}_{\mathrm{pr}}$ : radiant temperature asymmetry PD: percent dissatisfied due to local discomfort caused by $\mathrm{A}$ : warm ceiling, B: cool wall,

C: cool ceiling, D: warm wall. Source (EN 16798-2

TR 2014) monitored (Fig. 5) and represented in Fig. 9. The curves indicate clearly that indoor air temperature followed indoor surface temperatures. The indoor surface temperature of the glazed partition of the wall (TS2) was higher than indoor temperature, with a maximum difference of $13.1^{\circ} \mathrm{C}$ and a mean difference of $7.6^{\circ} \mathrm{C}$. According to ISO 7730 standards (ISO 7730-2005), this situation of asymmetric radiation may cause supplementary thermal discomfort (local discomfort) during occupied hours.

Radiant asymmetry created by a warm vertical surface (the window) causes local discomfort and reduces the thermal acceptability of the space. It was determined by the projection of the maximum discard $\left(13.1^{\circ} \mathrm{C}\right)$ on the chart (Fig. 10). The curve provides an estimate of expected percentage of dissatisfied oc- 
cupants (PPD) affected by radiant asymmetry, equal to $2 \%$. It seems clear that the presence of an oversized window deteriorate the comfort conditions in the hot period of the year.

\section{Predicted Percentage Dissatisfied (PPD) Index}

The parameters measured by the Delta ohm station (HD32.3) were used to calculate the PMV value, in accordance with Fanger equations (Eq.2 and Eq.3), (Fanger 1986). The Predicted percentage of dissatisfied people (PPD) is subsequently determined.

$\mathrm{PMV}=\left[0.303 \times \mathrm{e}^{-0.036 \times \mathrm{M}+0.028] \times \mathrm{L}}\right.$
$\mathrm{PPD}=100-95 \times \mathrm{e}^{-\left(0.03353 \times \mathrm{PMV} V^{4}+0.2179 \times \mathrm{PMV}^{2}\right)}$

Where the different terms represent, respectively: PMV = Predicted Mean Vote Index; $M=$ metabolic rate $\left(\mathrm{W} / \mathrm{m}^{2}\right) ; \mathrm{L}=$ thermal load $\left(\mathrm{W} / \mathrm{m}^{2}\right)$ defined as the difference between the internal heat production and the heat loss to the actual environment, for a person hypothetically kept at comfort values of skin temperature and evaporative heat loss, by sweating at the actual activity level; PPD= Predicted percentage of dissatisfied.

The total clothing insulation value and the metabolic rate were set at $0.75 \mathrm{Clo}$ and $1.33 \mathrm{MET}$ respectively, according to the charts given in ANSI/ASHRAE Standard 55, 17 (2017) which relates to seated office activities. Results from the comfort calculator of Delta ohm station indicate that occupants experienced a thermal discomfort in the office space, with a mean PPD value of $69.6 \%$ (Fig. 11).

\section{Comparison of Measurements in All Monitored Offices}

To examine the thermal environment of office spaces in the other directions (NE, NE/SE, and $\mathrm{SW}$ ), three office spaces were examined. Fig. 12 indicates the presence of overheating, as indoor temperatures in SE and SW orientations were well above the upper comfort bound in $100 \%$ of the working time, and 96 and $86 \%$ in NE-SE and NE respectively. Occupants working in these office rooms may endure serious indoor thermal discomfort. According to Allab et al. (2017), an additional decrease of the productivity, around $2 \%$ occurs for each temperature difference of $1^{\circ} \mathrm{C}$, over the comfort limit. Based on this research finding, when the indoor air temperature reaches its maximum value of $38^{\circ} \mathrm{C}$ in south west orientation, a decrease of productivity of $20 \%$ is esteemed.
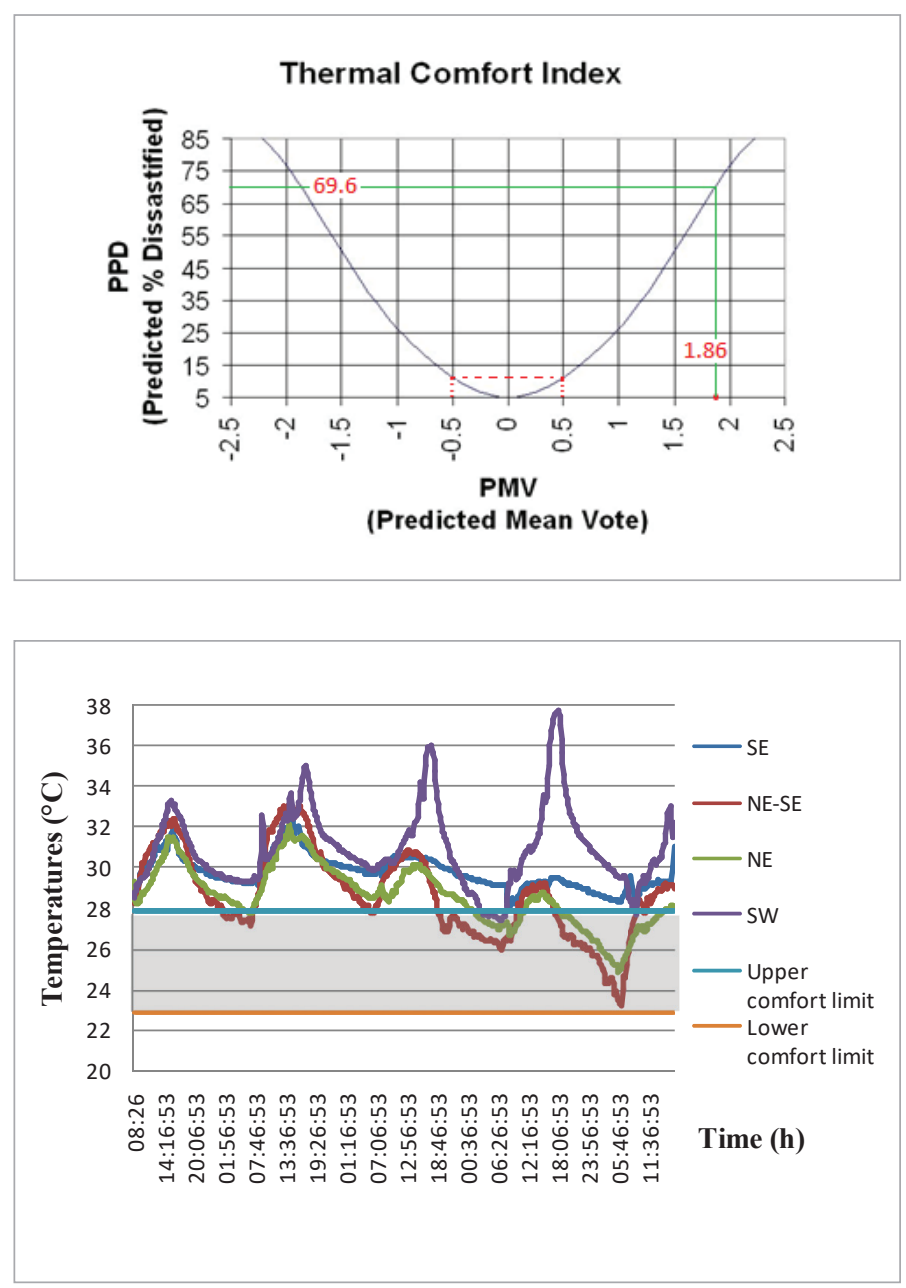

Fig. 11

Predicted percentage dissatisfied (PPD) as a function of predicted mean vote (PMV)

Fig. 12

The indoor air temperatures profile between 03 and 07 August 2014, for all the examined orientations 
Fig. 13

Absence of urban solar masks, in the surrounding urban environmentof the monitored office rooms

Fig. 14

The PhotoRadiometer sensor held at a horizontal position, during the horizontal illuminance measurements

\section{Illuminance}

The present analysis focuses on evaluating visual comfort based on two indicators that influence the quality of daylight; uniformity rate, and illuminance availability. Illuminance is defined as the total luminous flux incident on a surface per unit area measured in lux or foot candles. Uniformity describes the evenness of illuminance distributed across a working area (Freewan and Al Dalala 2019). The uniformity rate determines how brightness is distributed in space (Nasrollahi and Shokry2020). It's calculated according to the Chartered Institution of Building Services Engineers (CIBSE) as the ratio of the minimum illuminance to the average illuminance over the specified task areas (Guide LG10 1999).

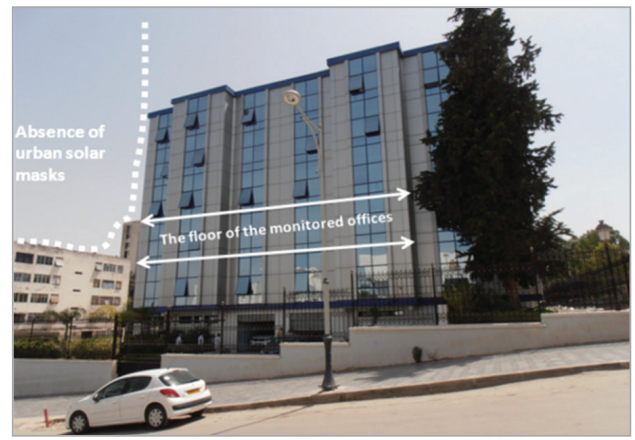

The illuminance measurements of horizontal work plane $(0.75 \mathrm{~m}$ from the floor level) were taken under clear sky conditions without any contribution of the artificial lighting system. Field measurement took place in one of the study office rooms (SE office room) at the second floor of the OPGI building. The location of the monitored office room, allows protection against environmental solar masks (Fig. 13).

The office room was $9.00 \mathrm{~m}$ long, $4.5 \mathrm{~m}$ wide and $2.70 \mathrm{~m}$ high. The window is positioned on the South East (shorter) wall. As mentioned earlier (in the section: Description of the monitored building), the window is a standard double glazed window with a low-e coating. The light transmittance (LT) of the glazing is 0.37 .

The horizontal illuminance levels were carried out using a Photo-Radiometer HD2302 at 9:00 am, 12:00 am, and 14:00 pm, on a partially overcast summer day. Photo-Radiometer HD2302 can measure the intensities between $0-199.99 \times 10^{3}$ lux with an accuracy $<4 \%$. As a reference value outdoor illuminance levels (klux) were measured simultaneously. The author moved in the space from one point of the appropriate grid, to another to collect data, with a reasonable duration of 15 minutes. The lux meter was held at a horizontal position, for ensuring accuracy and stability (Fig. 14).

\section{Results and discussion of illuminance levels}

Class II measuring:

The measured data have been compared to standards requirements and guidelines, such as the ISO 8995-2002 (2002) and the European norm EN 12464-1:2011 (2011). Which, specify a threshold for work plane and its surroundings in office spaces varying between 300-500 Ix. Data analysis showed that the illumination level in the monitored space, did not meet the illuminance criterion set by the standards, and the space is under-illuminated and not receiving adequate daylighting. This is attested by the mean horizontal illuminance values calculated for all measuring times that were strongly lower than $300 \mathrm{~lx}(278.80$ and $67 \mathrm{~lx}$ ) at 9:00 am, 12:00 am, and 14:00 pm respectively 
(Fig. 15, 16, and 17). The outdoor illumination values which reached 951.70 klux presented a significant potential for daylighting, while interior illuminance levels were very low. This is very probably linked to three main factors:

1. The number of glazing layers which produces lower U-values, but also lowers the visible transmittance (Tvis) of the skylight at a ratio of $40 \%$ (Guide LG10 1999).

2. The tinted glass has lower spectral transmittance values for the whole spectrum ranges compared to a clear glass of the same thickness.

3. The presence of a coating film in the fenestration system which lowers the solar heat gain by increasing reflectivity, has a bad effect on daylight transmittance, and creates "dark" interiors. According to Mousavi and Safari (2020), colored or coated glass can reduce the visible transmittance of a windowpane to values as low as $20 \%$.

\section{Results and discussion of illuminance uniformity}

The analysis of daylight distribution indicates the presence of higher illuminance near the window, and very low illuminance at far points of the grid (at 9 meters of glazing). The illuminance values related to the first line (located beyond $1.5 \mathrm{~m}$ from the windows directly) denotes the impact of low transmittance of the glazing under direct sunlight.
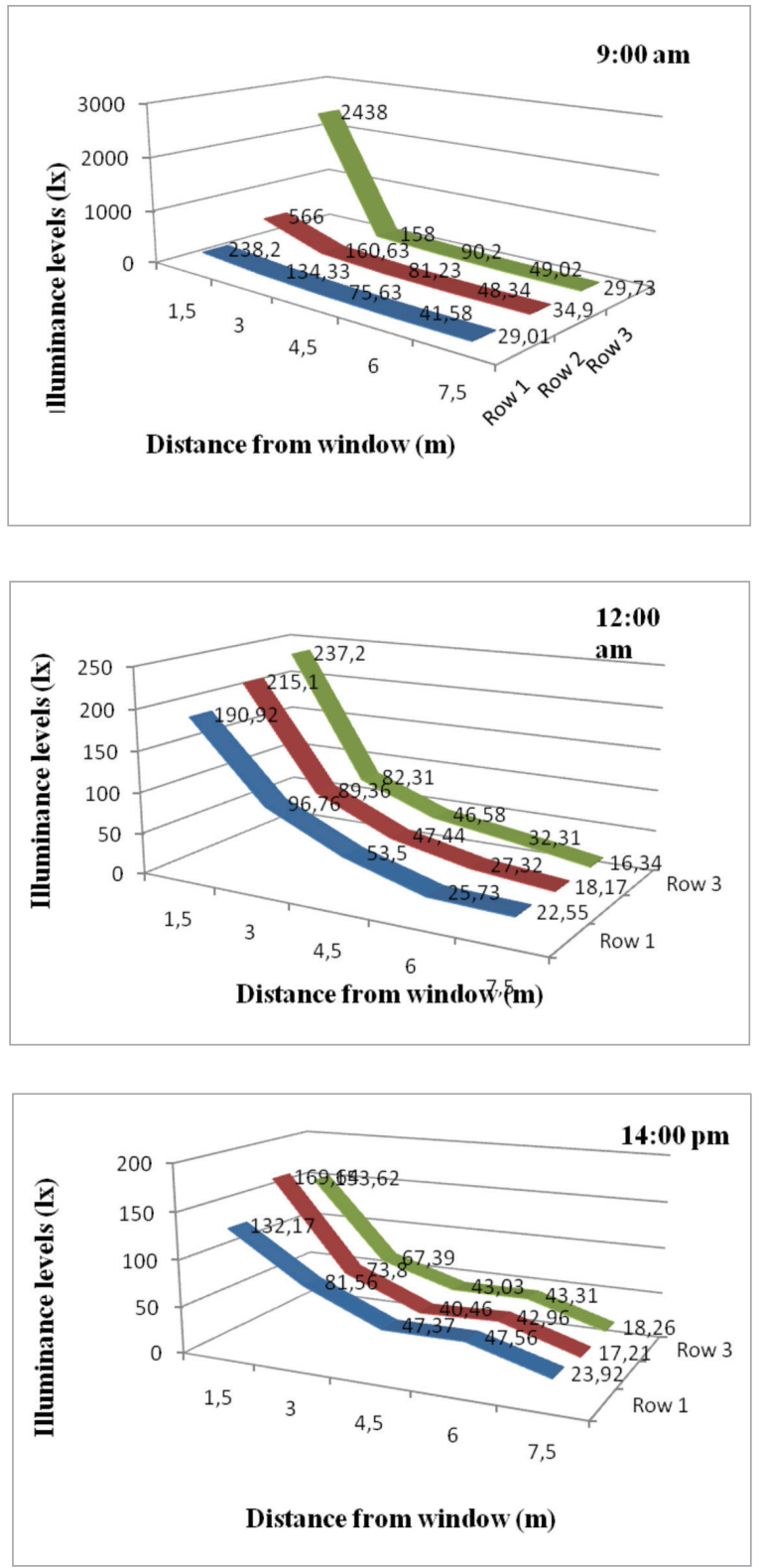

Fig. 17

Indoor illuminance distribution inside the monitored office (SE) at 14:00 pm

Illuminance uniformity is used to evaluate the daylight distribution in the space. It is defined as the ratio of minimum illuminance to average illuminance on a surface EN 12464-1:2011 (2011). The Illuminance uniformity values calculated for 9:00 am, 12:00 am, and 14:00 pm: were 0.01, 0.2, and 0.25 , respectively. Well below the threshold value (0.7) recommended by EN 12464-1:2011 (2011). They indicate a poor daylighting quality: over-illuminated areas close to windows and under-illuminated areas in the back of the room. This situation can be explained by the deep room configuration. The average illuminance calculated shows that the evaluated office room does not have the necessary lighting conditions to be used for the office workers visual tasks.

Many glare methods have been utilized for predicting and quantifying discomfort glare issues inside a building. In this study we focused on identifying potential problem areas where glare is a concern and visual acuity is critical. This technique is generally used for analysis in work where people need appropriately balanced lighting to function well. 


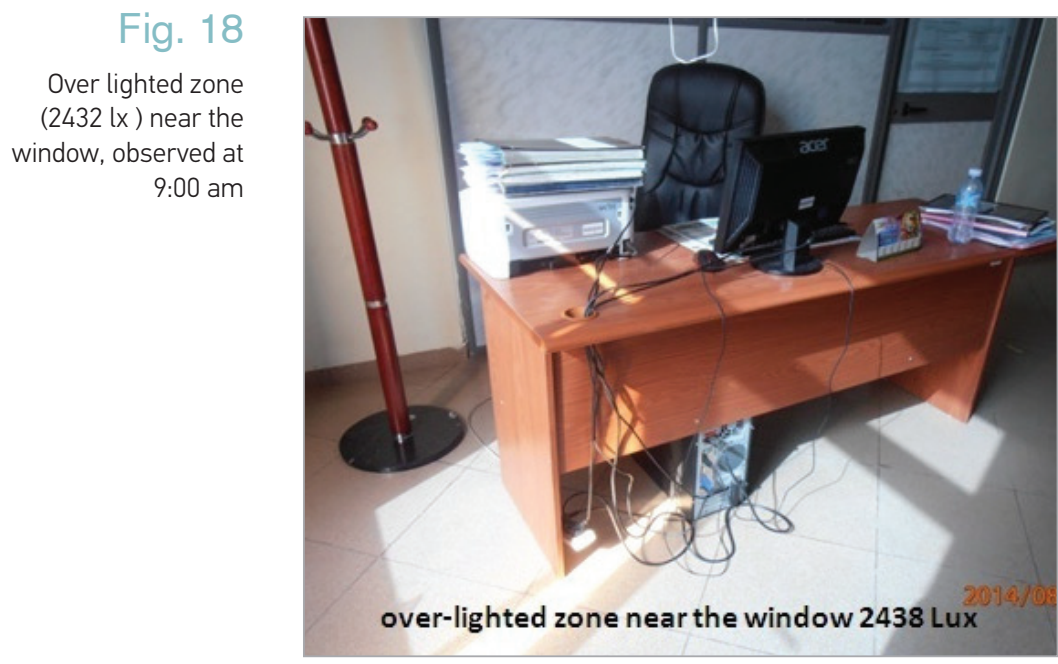

Office workers endure uncomfortable glare from high or non-uniform brightness. Indeed, the peak of illumination $(2438 \mathrm{~lx}$ ) measured at 09.00 , on the work plane, at a distance of $1.5 \mathrm{~m}$ from the window indicates the presence of discomfort glare from daylight, while working at a computer (Fig. 18). This value exceeds 2000 lux, which is the predefined threshold for achieving visual comfort (Nabil and, Mardaljevic 2006)._This workspace with poor uniformity could have inverse impact on human performance (Freewan and Al Dalala 2019).

Environmental comfort in buildings depends considerably on building performance envelope, particularly the glazed area. This study provides some fundamental ideas to understand the thermal behaviour of large glazed areas and highlights building envelope related problems, in semi-arid climate characterized by summer intense solar radiation. The approach in this research has been focused on a post occupancy evaluation conducted in a real office building. The results reveal that indoor environment responds poorly to thermal and visual comfort requirements in the working place, and requires a high energy input to cool to comfortable temperatures, and to illuminate properly work plans. In the hot period of the year, the glazed part of the facade used without efficient shading may become a source of occupants' discomfort in the perimeter zone of office buildings, due to high penetration of solar radiation and radioactive heat exchange between the human body and the glazing system inappropriate for semi arid climate. The operable part of the window is undersized; in fact it is unable to effectively control the natural ventilation. In addition, the absence of night ventilation takes part in thermal comfort deterioration, because, excess heat is accumulated in the space the following day.

The need for defining the optimal size is well established, particularly within the context of naturally ventilated buildings. The definition of glazing size for avoiding problems of glare and overheating, and ensuring an optimal illuminance level is much complex for semi arid climates, where high solar radiation plays a prominent role in defining indoor environment.

Indeed, the use of tinted glazing and coating film to protect interior space from solar radiation improves thermal comfort, but at the same time has a bad effect on daylight transmittance, and creates "dark" interiors in the workplace.

Therefore, the judicious choice of the glazing type must balance lighting and thermal needs. Mobile shading devices which prevent the penetration of solar radiation into the building in summer play an important role in managing visual environment, by controlling glare and reducing contrast ratios. This often leads to increased satisfaction and comfort. Several innovative building envelope technologies and concepts are promising solutions to improving indoor comfort conditions, such as adaptive solar façade and smart glazing.

The window design must be part of an integral ergonomic design process, considering simultaneously multiple aspects in order to guarantee thermal and visual comfort. A subsequent step will be to undertake simulations of all those parameters, to determine the most effective fenestration system for the studied climate, for both thermal and visual comfort. 
Al horr Y., Arif M., Katafygiotoua M., Mazroei A., Kaushik A, Elsarrag E. Impact of indoor environmental quality on occupant well-being and comfort: A review of the literature, International Journal of Sustainable Built Environment, 2016; 5 (1): 1-11. https://doi.org/10.1016/j.ijsbe.2016.03.006

Allab Y., Guo X., Pellegrino M, Nefzaoui E, Kindinis A. Energy and comfort assessment in educational building: Case study in a French university campus, Energy and Buildings, 2017; 143: 202-219. https:// doi.org/10.1016/j.enbuild.2016.11.028

ANSI/ASHRAE. Thermal Environmental Conditions for Human Occupancy, (Standard, 55). American Society of Heating, Refrigerating and Air-Conditioning Engineers. Atlanta, GA; 2017.

Badeche M. Optimisation de la surface vitrée pour un confort thermique et une efficacité énergetique dans les bâtiments à occupation intermittente à Constantine. Thèse de doctorat en sciences. Université Salah Boubnider, Constantine 3, Algeria, 2018.[Glazed area Optimization for thermal comfort and energy efficiency in buildings with intermittent occupation in Constantine, Thesis Submitted to The university for the degree of doctor of philosophy, University of Salah Boubnider, Constantine 3, Algeria, 2018].

Chi D.A., Moreno D., Navarro J. Correlating daylight availability metric with lighting, heating and cooling energy consumptions, Building and Environment, 2018; 132: 170-180. https://doi.org/10.1016/j.buildenv.2018.01.048

Chyee Toe DH., kutoba T. Development of an adaptive thermal comfort equation for naturally ventilated buildings in hot-humid climates using ASHRAE RP-884 database, Frontier of Architectural Research, 2013; 2 (3) : 278-291. https://doi.org/10.1016/j.foar.2013.06.003

CIBSE Guide A. Environmental Design, The Chartered Institution of Building Services Engineers (CIBSE), 8th edition, 2015.

EN 12464-1:2011, Light and lighting - Lighting of work places - Part 1: Indoor work places. European Committee For Standardization. Brussels, 2011.

EN 16798-2 TR. Guideline for using indoor environmental input parameters for the design and assessment of energy performance of buildings, European Committee for Standardization, Bruxelles WG19-N89; 2014.

Fanger, P.O. Thermal Comfort. Analysis and Applications in Environmental Engineering, Danish Technology Press: Copenhagen, Danmark, 1970.

Fanger P. O. Thermal environment - human requirements, The Environmentalist, 1986; 6: 275-278. https://doi.org/10.1007/BF02238059
Freewan AAY., A. Al Dalala J.A. Assessment of daylight performance of Advanced Daylighting Strategies in Large University Classrooms; Case Study Classrooms at JUST. Jordan University of Science and Technology, Alexandria Engineering Journal, 2019; 59(2):791-802. https://doi.org/10.1016/j.aej.2019.12.049

Göçer Ö., Hua Y., Göçer K. Completing the missing link in building design process: Enhancing post occupancy evaluation method for effective feedback for building performance, Building and Environment, 2015; 89: 14-27. https://doi.org/10.1016/j. buildenv.2015.02.011

Guide LG10. Daylighting and window design Lighting, lighting guide LG10, CIBSE, The Chartered Institution of Building Services Engineers, London; 1999.

Peixian Li. systematic investigation of thermal comfort compliance criteria. Thesis submitted in partial fulfillment of the requirements for the degree of doctor of philosophy .university of british Columbia; 2020.

Isaksson Ch., Karlsson F. Indoor climate in low-energy houses-an interdisciplinary investigation, Building and Environment, 2006; 41: 1678-1690. https://doi.org/10.1016/j.buildenv.2005.06.022

ISO 7730. Ergonomics of the thermal environment -Analytical determination and interpretation of thermal comfort using calculation of the PMV and PPD indices and local thermal comfort criteria, Third edition, 11-15; 2005.

ISO 8995 (2002) (E). International Standard. Lighting of indoor work places. Second edition 2002-05-15. Switzerland; 2002.

Jamrozik A., Clements N., Hasan S S., Zhao J., Zhang R., Campanella C., Loftness V., Porter P., Shaun L., Wang S., Bauer B. Access to daylight and view in an office improves cognitive performance and satisfaction and reduces eyestrain: A controlled crossover study, Building and Environment, 2019; 165 :106-379. https://doi.org/10.1016/j.buildenv.2019.106379

Laforgue P., Souyri B., Fontoynont M., Achard G. Simulation of visual and thermal comfort related to daylighting and solar radiation in office buildings, In: Proceedings of IBPSA Czech Republic; 1997.

Leaman A., Stevenson F., Bordass B. Building evaluation: Practice and principles, Build. Res. Inf, 2010; 38: 564-577. https://doi.org/10.1080/09613218.201 0.495217

Li D.H.W., Lam T.N.T., Wong S.L., Tsang E.K.W. Lighting and cooling energy consumption in an open-plan office using solar film coating, Energy, 2008; 33 (8): 1288-1297. https://doi.org/10.1016/j. energy.2008.03.002

\section{References}


Li P., Froese T., Brager G. Post-occupancy evaluation: State-of-the-art analysis and state-of-thepractice review, Building and Environment, 2018; 133: 187-202. https://doi.org/10.1016/j.buildenv.2018.02.024

Manz H., Urs-Peter M. (2012), Energy Performance of Glazing in European Climates, Renewable Energy 37: 226-32. https://doi.org/10.1016/j. renene.2011.06.016

Meir I.A., Garb Y ., Jiao D., Cicelsky A . Post-Occupancy Evaluation: An Inevitable Step toward Sustainability, Advances in Building Energy Research, 2011; 3 (1): 189-219. https://doi.org/10.3763/aber.2009.0307

Menzies G.F., Wherrett J.R. Windows in the workplace: examining issues of environmental sustainability and occupant comfort in the selection of multi-glazed windows, Energy and Buildings, 2005; 37: 623-630. https://doi.org/10.1016/j.enbuild.2004.09.012

Mousavi Asl SR., Safari H. Evaluation of daylight distribution and space visual quality at medical centers through spatial layout, Journal of Asian Architecture and Building Engineering, 2020. https://doi. org/10.1080/13467581.2020.1800476

Nasrollahi N., Shokry E. Parametric Analysis of Architectural Elements on Daylight, Visual Comfort, and Electrical Energy Performance in the Study Spaces, Journal of Daylighting, 2020; 7: 57-72. https://doi.org/10.15627/jd.2020.5
N.O.M. National office of meteorology. Climatic Data of Constantine City for 10 Years, http://www .meteo.dz, 2016.

Ochoa CE., Aries MBC. Loenen EJ Van., Hensen JLM. Considerations on Design Optimization Criteria for Windows Providing Low Energy Consumption and High Visual Comfort, Applied Energy, 2012; 95: 238 45. https://doi.org/10.1016/j.apenergy.2012.02.042 Sanni Anibire M.O., Hassanain M.A., Al-HammadA.-M. Post-Occupancy Evaluation of Housing Facilities: Overview and Summary of Methods, J. Perform. Constr. Facil, 2016; 30. https://doi. org/10.1061/(ASCE)CF.1943-5509.0000868

Stone P.T. The effects of environmental illumination on melatonin, bodily rhythms and mood states: a review, Lighting Research and Technology, 1999; 31:7179. https://doi.org/10.1177/096032719903100301

Tzempelikos A., Athienitis Andreas K. The impact of shading design and control on building cooling and lighting demand, Solar Energy, 2007; 81: 369-382. https://doi.org/10.1016/j.solener.2006.06.015

World Maps of Köppen-Geiger climate classification (accessed 2019). http://koeppen-geiger.vu-wien. ac.at/present.htm.

Wu J. Thermal Comfort and Occupant Behaviour in Office Buildings in South-East China, Thesis Submitted to The University of Nottingham for The Degree of Doctor of Philosophy, University of Nottingham; 2015.

\section{About the Authors}

\section{MOUNIRA BADECHE}

\section{Lecturer}

Department of Architecture, faculty of earth sciences and architecture, University larbi ben Mhidi, Oum el bouaghi.

Member of Laboratory of bioclimatic architecture and environment (A.B.E), university 3 constantine, Algeria

\section{Main research area}

My research interests focus on Energy efficiency in buildings, Healthy buildings, and Environmental building adaptation.

\section{Address}

Department of architecture, Faculty of Earth

Sciences and Architecture, Larbi Ben Mhidi

University, Oum El Bouaghi 04000, Algeria.

Tel: 0021332563131

E-mail: badeche_mn@yahoo.fr

\section{YASMINA BOUCHAHM}

\section{Lecturer}

Prof, Department of Architecture and Urban

Planning, University 3, Constantine, Algeria.

\section{Main research area}

Energy efficiency in buildings, Environmental and Bioclimatic architecture.

\section{Address}

Department of Architecture and Urban Planning, University 3, Constantine, Algeria 25000.

Tel: 00213031786075

E-mail: ybouchahm2@gmail.com 